\title{
Symbolic Meaning of Agate Stone as a Local Knowledge of Agate Fans Community for Learning Resource Development of Social Studies
}

\author{
Dr. Agus Suprijono, M.Si \\ History Educational Department, Faculty of Social Sciences, The State University of Surabaya, Ketintang 60231, Indonesia \\ Email: prijono02@gmail.com
}

Doi:10.5901/mjss.2015.v6n3s1p527

Abstract

Research focus on agate symbolic meaning for fans and how they act on the meaning of it. Does the construction of agate symbolic meaning as the sociology of knowledge can be developed for learning resource of social studies ? The purpose of research is to find the relevance between agate symbolic meaning and the concepts of subject matter in social studies so that they can be developed for learning resource of social studies. The method used is phenomenology. The analysis technique used is Miles and Huberman models. The results of the study are agate symbolic meaning as esotericism and exoteric phenomenon. Agate esotericism phenomenon related to the function of fetish. Agate exoteric phenomenon related to the function for accessories. Agate amulets worn by the fans for the sake of power, dignity, leadership, and authority. This action is magic. Agate accessories associated with symbols of modernity. Agate is physically associated with the type of rock and rock characteristics. Agate symbolic meaning has scope sociology, geography, and anthropology, so agate can be developed into a theme for learning social studies as an integrated lesson.

Keywords: symbolic meaning, social studies

\section{Introduction}

Social studies has direct correlation to social and cultural life. Studying society and culture not just learn figurative. Learning about social studies which has a concern on social and cultural life is not only in concept but also as an extensive process of learning to do, learning to be and learning to live together. Social studies are operative learning process, according to Suparno (2001:141) figurative learning is learning that only emphasizes acquisition and addition of new information, whereas operative learning is learning to acquire and obtain more general structures of thought that can be used in various situations.

Along with the purpose of general education, social studies aim to build personality of students as a form of consciousness within their self, social world and culture. Social studies are not just learning facts and concepts of general organization of social and cultural life, which has been known, and the learners who do not know these things regard this as something new. Social studies are critical education that seeks to develop the ability of students to think critically and logically about various social phenomena that they encountered and experienced. The purpose of social studies is to synchronize the awareness of learners to achieve rational sense of their self, nature, the environment and life within the community.

In history of Indonesia, rocks have marked the growth and development of a mass culture of the Stone Age. This era is classified as prehistoric era and stone becomes a cultural focus. Stone serves as the equipment that supports human needs e.g. for hunting, cutting trees, planting, and skinning animals. Among the relics of the prehistoric stone tools are chopper, and flake.

Nowadays, stone does not become cultural focus for modern society, but the continuity of stone culture still exist in some Indonesian society, one of them is a fan community of agate. According to the dictionary of geological terms which is compiled by MM. Poerbohadiwidjojo, agate literally comes from the word agat. It means the silica mineral (SiO2), or amorphous quartz or colored and layered kriptokristalin (G Sujayanto, 1993: 137). In Handboek der Edelsteenkunde written by KE. Kinge, rock quartz are classified into four class of gemstones. This classification is valued through the hardness of rock that measured in mohs - named after its creator, Friedrich Mohs (Puw Kioe An, 1979:43)

According to geological formation, agate is produced by volcanic eruptions. Lava from the magma that has been kept within the earth containing minerals silica (SiO2), the lava goes out to the earth's surface through volcanic eruptions. When the eruption happens, other mineral materials also mixed within the lava. This mixture gives a various color to agate. 
The natural process of agate formation is not or less known by the public. The society has labeled agate with different names in accordance with their physical appearance and prices, beside the names, the society characterize the magical powers within the agate. "Ivory Agate" is commonly worn by sailors and fishermen, believed to have properties to degrade a tidal wave (Anandita, 1996:58), "Yekti Aji Agate" is beige, it is a symbol Dewaruci (God of Sea in Javanese mythology); it is perfect for fishermen, sailors, and the crew, believed to have properties to give protection and safety in traveling at sea. "Ni Laras" is little black, believed to have to have properties to give self-protection. "Cat's Eye Agate" is shiny, blackish green; the name implies that this agate has property to improve the user's responsiveness to their environment situation. "Kyai Abdullah Aziz Agate" has a property for home protection, "Tedjomurti" and "Sentanamurti," both have property to attract someone (Purwadi, 1996:7).

Many people search and buy agate not only its beauty but also they want to collect and treat it; because sometimes people believe it has supernatural powers. This reality is the actualization of the human experience of the sacred and the profane.

Sacred quality, according to Durkheim is not intrinsic to the object, but it is given to the object by human religious thoughts and emotion. Sacred or holy things are not empirical, but it is beyond. Purity is not real and clear element, which can help someone act against something; moreover, it has no connection with empirical knowledge, which is based on physical experience. Attitudes generated by sacred thing symbols are one of the noble respect; yet, profane experience is "world" routine experience (O'Dea, Thomas, 1985: 36-37).

Sacred experience is human experience toward non-empirical or supra empirical world. In this study, for example, non-empirical world contained in agate are supernatural forces, magic power, yoni, magic, luck, kodam and asmak. According to Codrington, those supra-empirical elements are called "mana." Mana is something that influences all things, which is beyond human power, and it is also anomalous and unreasonable (J. van Baal, 1987:129). This understanding has same definition to supernatural power: the power that is above ordinary natural forces and such forces has magic power (Koentjaraningrat, 1990:288).

Profane experience is human's experience of the empirical world in daily life. For example in this study, profane experience can be seen in the use of agate in terms of aesthetic and economic value; according to Glasner, this kind of experience is secular. This secular process is regarded as part of a trend of the three interrelated social changes principal namely, urbanization, industrialization, and modernization. Those three issues are the fact of modern society, in this society, human believes that there is no presence of typical supernatural force (esoteric); everything must obey rationality. This idea is supported by Weber in his essay, Science as a Vocation:

\section{Modern society is characterized by rationalization and intellectualization and, above all, by the "world disenchantment." Traditional values such as transcendental mystic life, family kinship and personal human relations have been eliminated from human daily life (Glasner, 1992:91).}

According to Nisbet $(1970: 383)$ there are several results of secularization to human character. Human tends to more respect towards the utility rather than the sacred values; moreover, human control the environment rather than passive obedience to them and in some ways human are very concerned about their welfare on earth rather than their relationships with God.

Agate has esotericism and exotericixm side, so students are not alienated to the knowledge of agate, because in big cities, there are many centers of agate. For example, in Surabaya, Agate centers exist at Pasar Turi and Kayoon Markets and both centers are located in the center of Surabaya. Every day, many collectors and fan get together in those places. Esoteric and general side of agate in its community, has several constructions of meaning; so, the question is, what is the meaning of agate to its' fan communities and how they act upon the meaning? Is the meaning construction of agate to its fan community as the sociology of knowledge can be developed into a source of social studies learning? The purpose of the study is to describe the sociology of knowledge on the meaning of agate and to know how its fan community acts upon the meaning construction. The study also aims to explain the relevance between the results of meaning construction of agate to its fans community and the development of social learning resources.

\section{Method}

The researcher applies qualitative approach in this study and the research method is phenomenology. The researcher uses observation and interview to collect the data, while to analyze the data the researcher uses Miles and Huberman models. According to Miles and Huberman (1994:10-11) data analysis includes data reduction, data display. Data 
reduction refers to the process of selecting, focusing, simplifying, abstracting, and transforming the data that appear in written-up field notes or transcription. Data display is an organized, compressed assembly of information that permits conclusion drawing and action. Conclusions drawing and verification are verified as the analyst proceeds.

\section{Results}

\subsection{Agate as Fetish/Amulets/Talisman}

Holy or sacred thing is something that is beyond the rational concept. What is involved in it is an unfathomable, hidden, and can only be comprehended by the esotericism feeling. This perception provides a starting point that revealing sacred thing does not reveal the substance of the issue of the sacred, but it has connection to human inner experience of the sacred and the things that underlie human appreciation of the sacred.

HM is a user of agate as a talisman; HM has worn agate as a talisman for almost ten years. Agate is wound around the ring; it has a name "gambar," HM believes that this agate has magical power (yoni) and he obtains this agate from mbah (old person who has supernatural powers). The story began ten years ago when HM was following an election to be a head department in certain university. The candidates were HM and ML and the result of the voting HM was in the second place. The process continued at the upper level (Faculty Senate), but the one who became the head of the department is HM. It happened because there were certain conspiracy, HM knew well that there were no colleague of $\mathrm{ML}$ in green flag (an organization affiliates to Islamic ideology) who served in the university. Since he was the chairperson of the department, HM felt uneasy. On certain nights since becoming head of the department, his heart troubled. HM tried to solve it by praying five times and after praying HM always asked to God to get his problem ended, yet the problem did not solve. Finally, he told his problem to colleague and he got a suggestion to meet HM Mbah (an old person who has magical powers and can help people to solve their problem.

When HM met Mbah, HM was given a package of paper, there is sand inside the paper, and Mbah asked HM to sprinkle the sand in the corners of the house and office. A week after his meeting with Mbah, HM came back and on the second visit, HM receive "Agate" but he must pay the "mahar" Rp. 150,000. While giving the agate, Mbah gave several message that the agate had not mix with gold ring because gold has hot energy so it could damage the supernatural power. Agate should not be taken to the bathroom and HM should always wear the agate wherever he/she go. Since wearing the agate, his uneasiness does no longer appear and HM believes that agate can give security and the safety to disturbances and powers of supernatural beings.

Beside a talisman (safety), some people believe that agate has mystical power as a pengasihan (to attract and captivate someone else). This phenomenon was found among the users of agate amethyst Pengasihan, one of them is SP. SP wears a ring on his ring finger of the right hand and the ring has a glowing purple gemstone. SP calls the stone ring with "Agate Amethyst Pengasihan." SP believes that the ring has supernatural powers to captivate others.

SP tells the origin why he wears this kind of agate. It started from hatred of the head of company where he works; SP sought to find a way to get a sympathy from his chairperson. SP felt that his boss hated him since his boss was not fair in distributing job. As a driver SP felt discriminated, because every overtime-hours his boss more likely to use another driver. It is no longer a secret that the driver will get tips, if a driver serves the boss duties outside working hours. He told his problem to his wife and she suggested him to meet a Kyai (a leader of Pesantren); his wife knew him because when she was Senior High School, Kyai was her teacher.

When SP met the Kyai, he gave SP Agate Amethyst "Pengasihan" in form of ring. SP says that when he wears the ring, there are several things that he must obey to make the supernatural power working. Those things are, he is not allowed to bring the ring into a bad place (a place in which there are a lot of sin happened), it is forbidden to place the agate within golden ring, because men are forbidden to wear gold, but women are allowed (Islamic law of gold). SP must provide the agate with fragrances such as "Japaron" and "Black Stone."

Besides those two meaning construction of agate, another phenomenon of agate is also useful for power and authority; this phenomenon will be unveiled by YT. YT wears a ring on his ring, it is an agate, silver ring, he calls his agate "agate bulu macan." YT feels every time whenever he wears the agate bulu macan he feels more commanding, many colleagues and subordinates are more respectful to him. The commanding in this situation means confidence to lead and face the people they lead.

YT said that by the mercy of Allah, his agate brought him to become a manager. YT told that he obtained the agate from the smart person (paranormal). When there was manager selection, YT assumes that in this insane world, people justify any means to get the position. Many ways are taken, from rational and irrational things. Therefore, to win the positions YT prayed to God Almighty, he also went for winning by meeting smart person (paranormal). This paranormal is 
an expert in khodam combination asmak inner energy, hypnosis, telepathy, telekinesis, sambatan, and debus. When he met this person, YT acquired agate "bulu macan." YT feels that he is able to influence and control his subordinates after he acquired this kind of agate.

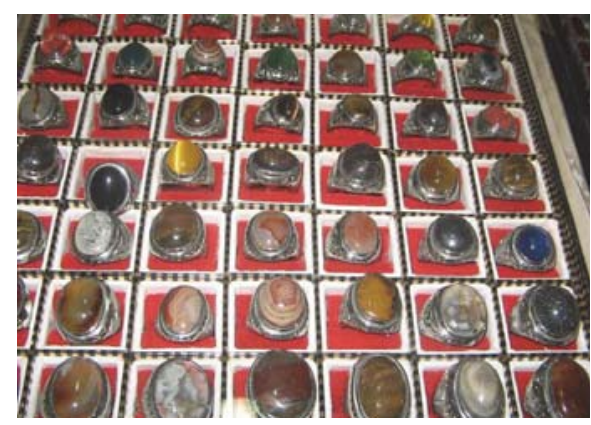

Picture 1. Diversity of Agate as Talisman

People in agate fans community believe that agate as a talisman has sacred power and magic. In this experience, this sacred stones has given a meaning, which has magical powers (yoni), and the sacred; it isolated from profane things. Based on those meanings, people are exploiting agate for pragmatic purposes as the researcher has described above, namely security, captivate others, authority and power.

In Islam, yoni and magic are abstracted as supernatural forces or supernatural beings. Turner (1994:94) indicates that one of the magical powers referred by Islam in this matter is a genie. Now, the reality happens among the fans community of agate, none other of that kind of forces are conceptualized as supernatural or non-empirical power, or powers that are beyond natural forces. Durkheim states even though that power manifests the experience and lies outside itself; this power is the highest power that instills human respect to that kind of strength.

Academician, by using original religion reference can explain yoni, magic, and the mystic power that exist in certain objects and how human can exploit the forces. Rahmat (1979:23) states, according to original religion, every object has different soul and strength; the spirit or soul from one thing can move or be moved as well to human. Human can strengthen themself by mastering the power of these objects.

The views and beliefs of agate community as talisman, those supernatural powers that lie within in the stone indicate that their religiosity is still adhering to the religious traditions of the original convention. There are two paradox things among these people, one side, as a Muslim, they try to keep the Islamic practice such as five daily prayers, recite the Koran, but on the other side they still believe to the traditional value (in this case is Javanese culture). In this religious phenomenon, it is difficult to categorize people who exploit agate as a talisman into one of the categories, which has been made by Geertz, the abangan and santri.

The religious behavior of these people who exploit agate as a talisman, if we refer to Geertz opinion can refer to them (agate fans). Santri can also be classified as abangan. It is not easy to answer the question; therefore, this case is a critique to Geertz theory and shows what Nurcholish Madjid means as misconceptions of Geertz theory. Geertz assumption is every element that is taken outside, as a cultural concoction religion (Islam) will negate the essence of Islam. This assumption is contrary to the historical facts, including at the time of the Muhammad, he takes many elements from the local culture in spreading the message (Herman, 1985:24). This case is at least a proof that the natural Javanese thought is the result syncretism of Javanese tradition, Hinduism, Sufism or Islam and Islamic mysticism (Boediono, 1984:72).

Construction meaning of agate to be a sacred experience for its fans as a talisman is based on sense. It is obvious after they wear agate, they become calm, optimistic, confident, and commanding. This phenomenon can be explained through Geertz theory on Javanese religious phenomenon by incorporating a sense of culture. According to Geertz, the Javanese, the current subjective experience which is taken in its phenomenologist is a micro-cosmos of the universe in general. In the inner world, thoughts and emotions are expressed through sense.

The sense has a basic quality in form of feeling and meaning. As the feeling, the sense is one of the five senses of the Javanese, so they have opinion of five separate senses: taste on the tongue, a touch on the body, and the emotional feeling in the heart. As a meaning, a sense can be applied to the words in daily communication and social relationships. The sense is also applied to indicate the charge implicit behavior (Geertz, 1993:61).

Responding to its sense, the agate's holders can develop complex phenomenologist analysis in regard with their personal experiences. The subjective experiences are considered to be objective because their spiritual experiences are 
relied on the sense and meaning; an investigation on spiritual perceptions resulted in metaphysic analysis on the physical realism. The main purpose is to obtain emotional peace. Therefore, any efforts are dedicated not only through vertical relations with their God, but also "strength" emitted from the agate.

Priest, fortuneteller and Mbh play a significant role in searching the agate. The agate lovers believe that they are knowledgeable dealing with the issue. They assert that a priest is good at Islamic knowledge and so the fortunetellers are: they know the majesty of God and the mystery of the universe. That paradigm is associated with what Weber mentioned as charismatic authority. The agate's lovers acknowledge that the priest, fortunetellers, and Mbh are the right persons to achieve their goals and interestingly, their mastery are socially proven (Soerjono, 1990 : 311).

\subsection{Agate as a accessories}

According to Kuntowijoyo $(1987: 87)$, the things that are thought to have supernatural power and commonly used function not only for magical purposes, but also for self satisfaction.

The agate collectors do not use the agate for fetish. It has nothing to do with magical power that it brings. They do not have any sacred experiences during they wear it. They, however, assume that it is a priceless, beautiful, shining and ornament jewelry. Indeed, the agate is an accessory, an exotericism realm.

$\mathrm{JK}$ is the agate collector. We can find a wardrobe especially used to keep his agate collection. The examples of his collections are pirus agate, Solaiman wulung sembahyang agate, biduri bulan agate, biduri laut agate, biduri anggur agate, mata kucing agate, selendrit agate and a variety of safir agates. He has collected them since he was young. He bought from the agate sellers at Surabaya, such as in Taman Kayoon, Pasar Turi, Jalan Panggung, Wonokromo, Pandegiling, Sari Agung dan Plaza Tunjungan. A part of them are purchased in Makah when he went to pilgrim at 1995.

According to JK, the prices are various, ranging from a thousand to a million. The originality, the variety and weight of the agate influence the price. JK argues that all agates he has are not genuinely agates. They are not all magical. They are only accessories. He has no belief as others do. Accordingly, believing in agates is polytheist. Indeed, that behavior refers to syirik.

The agate lovers do not automatically mean as a collector of agate. Nevertheless, they wear it. Mr GD is evidence. He argues that agate have no magical values. Accordingly, if most of people assert that agate brings magical power, it is only pseudo science.

We can find agate on Mr. GD's ring finger named ruby. Ruby means red. Based to Srilanka history, the red agate was derived from gods. Mirellia Gangga River flows where Amoule land is fertile. It makes the inhabitants prosperous. Once upon a time, a god passed through that river with clean water. When he wanted to drink it water, his hands were bloody due to spins. The drops of bloods cover sand of the river and transform into red stones (ruby). GD's agates have three stars light mentioned three ster. It costs Rp. 1.500.000. He is proud of it and it is getting more expensive because it becomes his golden ring. GD said that it makes him look "wow" when he is wearing it.

TP is an agate lover as well. TP has three agates: Red ster agate, mata kucing (cat eye), and blue sphire. They are the most beautiful accessories he wears. He decided to purchase them because he found such matchness between his golden ring, agates and himself. He bought his all agates based on that reason. Reasonable price is another reason to why he did. Even he made trade-ins to get such interesting agates.

He wears his agates in his daily activities either at his house or at his office, in his right and left fingers. What he wears is the couple agates from any variations. It has been years he normally lives in this way, nothing to do with mystical practices. It is only a social symbol.

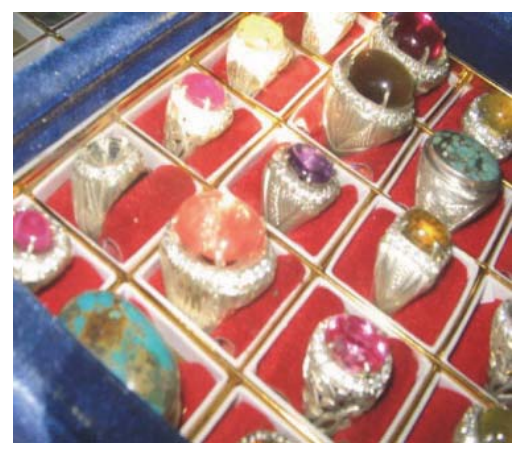

Picture 2. Diversity of Agate as Accessories 
The data shows that syirik is a term used in academic sphere addressed to agates lovers especially for Muslim. It means that they equate Allah with his creatures. Therefore, they believe that the agate lovers polytheistic.

According to cognitive antrophology, syirik is a symbol of agate lovers as an accessory. It indicates their conception of the agates. Symbol and syirik demonstrate such distrust of the agate lovers to any kinds of supernatural power beyond the God. This attitude is an indicator how strong they are in manifesting Islamic values. In line with Geertz categorization, the agate lovers are categorized as (Islamic) students.

The context of the second meaning of the agate as an accessory is secularism, Glasner stated. It refers to a profane experience of the users. Secularism itself consists of two connected transformation in human mind. The first is the desecration and rationalization is the second. The first perspective assumes that emotional engagement in responding the holy and religious affairs is excluded. The rationalization, on the one hand, believes that emotional roles are important in understanding the world (Glasner, 1992 : 93).

Referring to Glasner's view, secularization's symptom spreads along with the modernization process, commercialization, and the increasing number of middle class society in urban areas. They are intellectuals, traders and businessmen. In modern culture, they tend to discrete the subject from the object, human from the universe, individuals from community, living things from inanimate, sacred thing from profane, and the world from God. Human needs time to think objectively, and disregards this profanity from the holy. It makes this world as a separate entity (desecration) which simultaneously human puts the gaps between experiences and faith (Nico, $1990: 66$ ).

From the above point of view, it can be argued that people in modern cultures are getting busier with profane business. It motivates humans to look for a status as a social symbol after they position in a certain level in their society. It has been shown by the fact that the agate lovers purchase agates in malls with a high price.

\subsection{The meaning of agate: as a theme and a source for social studies}

Semantically, this investigation finds two categorizations: esoteric and exoteric. The first one refers to an agate as a charm and the second functions as an accessory. Esoteric side is a cultural manifestation of human spirituality. In social science, culture in this context is a subject of cultural anthropology. The students learn the basic concept of esoteric; magic and religion are the focus of the learning. There is a relationship between esoteric phenomena of the agate and magical and religious concepts within agate lovers' communities.

The agate reflects power and authority. This phenomenon shows two ideas of power in a real society. Anderson (1991 : 50-52) states that power is seen from 'west' perspective. This belief assumes that power is an abstraction visualized from visible social interaction. Wealthy, social status, social position, institutional power and organization are the sources of the power. On the other side, power is an untouchable, mysterious and divine object. To get this kind of power, people have to isolate themselves and fast. This power is homogeneous and similar in term of the source. Koentjaraningrat $(1991: 138)$ argues that Javanese acknowledges that power is sacred and magical which exist in human environment in real. Therefore, the leader assumes when they have such power such as through keris derived from palace, the power is naturally attached to them so that they can exercise their power in their society. It shows that there is a significant relevance between esoteric phenomena of agate and the concept of leadership, power, authority studied in social sciences, Sociology.

On the other hand, exoteric side is a material cultural manifestation. In this level, agate functions as an accessory. It refers to profane experiences of individuals towards their empirical world in their daily life. In agate lovers' communities, those experiences are manifested in esthetic purposes and economic values when they wear them or what we called secular experiences. Meanwhile, the secularization is seen to be the source of three roots of social changes: urbanization, industrialization, and modernization. Those three phenomena are factual of modern society. Therefore, the exoteric phenomena of agate are relevant with modern concept which is covered in sociology.

The physical aspect of the agate is stones. In geology perspective, stones have their own stories ranging from the process of the creations, varieties and characters. Agate can be a medium of learning that they are covered in geography.

The meaning of agate developing in the agate lovers' community can be a source of social science for developing the knowledge in the field of sociology to be integrative social sciences. The integrative approach emphasizes the linkage and relationship among major of sciences. Thematic approach is significant to integrative social sciences.

Sutirjo (2005: 6) argues that thematic approach is a strategic learning strategy that includes other disciplines to give worth experiences to students. The current approach allows them, individually or collectively, to search, explore and invent the holistic, meaningful and authentic concept of sciences. Thematic learning will take place when the authentic events or theme explorations control the teaching-learning activities. Students should participate in exploring the theme 
so that they learn not only process of the learning but also the content of the subject holistically. The thematic learning began a certain theme that is connected to other theme, one concept to other concept that is applied spontaneously or purposefully. The various experiences shared will make learning more meaningful.

Thematic learning as one of the learning models is mainly focused on the teaching materials. The materials are designed to be integrative and planned to be thematic learning. It means that the teaching materials are integral with other disciplines. Therefore, some of teaching materials can be taught in one meeting. In other words, thematic learning is useful for students to experience what explained in the subject. Indeed, it benefits them in a way that they directly observe the object of the learning and connects them with the concept of the science they learn.

The thematic materials are expected to benefit students for instance: (1) students can mainly focus on one particular theme; (2) the students can learn and develop one major of the subject to be subsequently developed along with other majors of the same theme; (3) they get a deeper understanding of the subject; (4) the basic competence can be enhanced through their learing and their personal experiences; (5) the students enjoy the class because the teaching materials are clearly designed; (6) they are getting more anthusiastic because they can communicate in a real situation to develop their competence of one particular subject and simultaneously acquire the different subject of theri major; (7) the teachers can spend time effectively as they designed materials for one meeting but can be used to other meeting. They can manage the time for remedial activities, drillings or enrichment. Indeed, this method allows the students to experience in finding something new in the process.

The agate phenomena is one of the sociological science that can be developed for integrated social science learning. The concept of magic, religious, modernity, leadership (power, authority) and the agate (various, process of creation and its characteristics) can be interconnected through the theme of the agate phenomena in agate lovers' communities. The theme refers to the main core of thought as the main source of the discussion.

Picture 1. The Learning of Social Studies by Using Thematic Approach "The agate: between fetish and accessories"

\section{Conclusion}

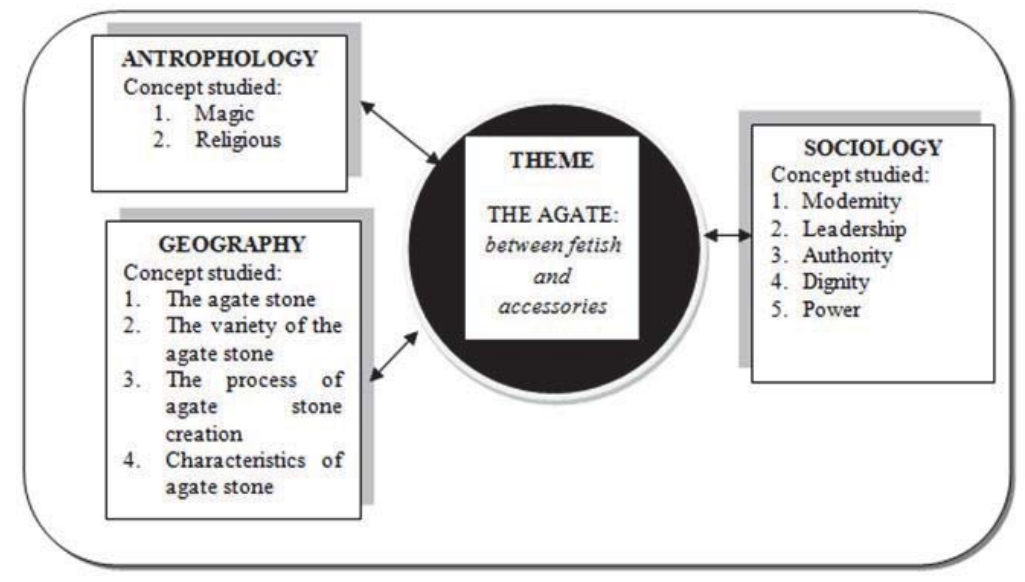

The meaning construction of the agate developed in the agate lovers' communities refers to esotericism and exoteric phenomena, fetish and accessories. In esotericism terms, the agate brings magical values. In contrast, the agate means a profane in exoteric realm.

The agete phenomena: between the fetish and accessories related to meaning construction refers to the fact of the concept of the rock, variety, the process of creation, its characteristics, magic, religious, modernity, leadership, authority and power. The given concept can be implemented in social sciences; geography, antrophology, and sociology. The agate phenomena in regards with esoteric and exoteric values can be developed as teaching-learning materials sources in social science.

Esotericism and exoteric values of the agate can be developed to be a thematic material in teaching social studies. The students not only understand the given concept easily but also learn the agate phenomena; between charm and accessories as a social reality developing in the agate lovers' communities accross subjects. Therefore, the students can learn social studies integratedly. 


\section{References}

Anderson, Benedict R.O'G, (1991), Gagasan tentang Kekuasaan dalam Kebudayaan Jawa dalam Miriam Budiardjo, Aneka Pemikiran tentang Kuasa dan Wibawa, Jakarta : Sinar Harapan.

Anandita, Daya Magis Batu-batuan Permata, Mysteri, No. 0174, Juli 1996.

Budiono, Herusatoto, (1984), Simbolisme dalam Budaya Jawa, Yogyakarta : Hanindita,

Geerts, Clifford, (1993), Kebudayaan dan Agama, Fransisco Budi Hardiman (penterj). Yogyakarta ; Kanisius.

Glasner, Peter. (1992). Sosiologi Sekularisasi: Suatu Kritik Konsep, Yogyakarta: Tiara Wacana.

G. Sujayanto dan Wied Harry Apriadji, Batu Akik: Mineral Silika yang dilihat Mistik, Intisari, Juli 1993.

J van Baal, (1987). Sejarah dan Pertumbuhan Teori Antropologi Budaya (Hingga Dekade 1970), jilid 1. Jakarta: Gramedia.

Herman Darmo dan Suyatna A, Mojokuto Setelah 32 tahun di Bawah Bayangan Kamar Bola dan Wiringin Budha, Buletin Antropologi, No. 5 tahun II. dikutip dari kompas, 5 November 1985.

Koentjaraningrat, (1991). Kepemimpinan dan Kekuasaan : Tradisioanl, Masa Kini, Resmi dan Tidak Resmi dalam Miriam Budiardjo, Aneka Pemikiran tentang Kuasa dan Wibawa, Jakarta : Sinar harapan

Koentjaraningrat, (1990). Beberapa Pokok Antropologi Sosial. Jakarta: Dian Rakyat.

Kuntowijoyo, (1987). Budaya dan Masyarakat, Yogyakarta : Tiara Wacana.

Miles, Matthew B, \& Huberman, A Michael, (1994), Qualitative Data Analysis, California: SAGE Publication.

Nico Syukur Dieter, (1990). Pengalaman dan Motivasi Beragama: Pengatar Psikologi Agama, Yogyakarta: Kanisius.

Nisbet, (1970). The Social Bond : an Introducation to the Study of Society. New York, Alfred Knoff.

O'de, Thomas, (1985). Sosiologi Agama : Suatu Pengenalan Awal. Yogyakarta : Rajawali Press,

Purwadi, Atasi Kesulitan dengan Benda Pusaka, Mysteri, No. 0176, September 1996

Puw Kioe An, (1979), Rahasia Batu Permata, Semarang: Mandira.

Rachmat Subagya, (1979), Agama dan Alam Kerohanian Asli di Indonesia, Jakarta : Nusa Indah,

Soerjono Soekanto, (1990), Sosiologi Suatu Pengatar, Jakarta : Rajawali

Suparno, Paul, (2001) Teori Perkembangan Kognitif Jean Piaget, Yogjakarta: Kanisius

Sutirjo, (2005), Pembelajaran Tematik, Yogjakarta: Pustaka Pelajar

Turner, Bryan S, (1994), Sosiologi Islam: Suatu Telaah Analitis Atas Tesa Sosiologi Weber, GA Ticoalu (perter), (Jakarta: Rajawali, 1994), h. $94-95$ 